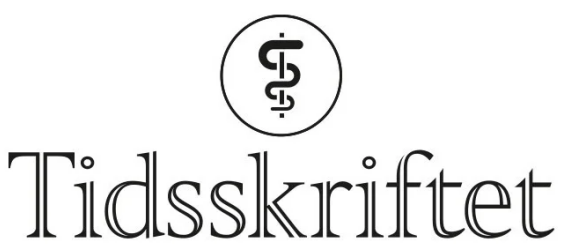

DEN NORSKE LEGEFORENING

\title{
Legionellasmitte fra fontener og andre vannkilder
}

LEDER

\section{SUSANNE HYLLESTAD}

susanne.hyllestad@fhi.no

Susanne Hyllestad er seniorrådgiver ved Seksjon for smitte fra mat, vann og dyr, Folkehelseinstituttet. Forfatteren har fylt ut ICMJE-skjemaet og oppgir ingen interessekonflikter.

\section{VIDAR LUND}

Vidar Lund er seniorforsker ved Seksjon for smitte fra mat, vann og dyr, Folkehelseinstituttet. Forfatteren har fylt ut ICMJE-skjemaet og oppgir ingen interessekonflikter.

\section{Prøvetaking og smitteoppsporing er avgjørende for å forebygge utbrudd av legionellose.}

Etter at Legionella for første gang ble beskrevet i Philadelphia i USA i 1976, har sporadiske tilfeller og utbrudd av legionellose blitt påvist verden over. Legionella pneumophila er den

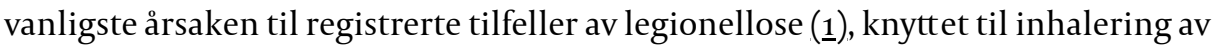
aerosoler fra vannbaserte systemer som under gitte forhold kan være ideelle for vekst av denne opportunistiske bakterien. Kjente risikofaktorer er blant annet høy alder og immunsuppresjon, og pasienter på sykehus og eldre på sykehjem er spesielt utsatt. Legionellose er meldepliktig i Norge, og evalueringen av overvåkningen av legionellose viser at Meldingssystem for smittsomme sykdommer (MSIS) fanger opp endringer i antall tilfeller over tid, men at ikke alle diagnostiserte tilfeller blir meldt (2).

Mye er gjort for å forebygge legionellasmitte, blant annet i form av regelverk og teknisk veiledning. Likevel forekommer det flere tilfeller årlig. Blant europeiske land har antallet registrerte legionellosetilfeller $\emptyset \mathrm{kt}$ de senere årene, med en topp i 2018 (3,4.). Man har forsket på effekten av ulike legionellaforebyggende tiltak, som behandling med varme, kjemikalier eller tekniske tiltak. Det er mindre dokumentert i hvilken grad rutiner for forebygging av Legionella er implementert eller etterlevd $(5, \underline{6})$. De siste årene er man blitt mer oppmerksom på faren for slik smitte, for eksempel har man inkludert krav til Legionella-overvåking i EUs drikkevannsdirektiv. $\emptyset \mathrm{kt}$ risiko knyttet til bygg som har vært periodevis stengt under covid-19-pandemien, har også ført til bekymring. 
«Kasuistikken viser også at det er viktig å ha en åpen holdning til hva

som kan vare smittekilden, etterforske bredt og ta prøver av relevante

installasjoner»

Tidsskriftet publiserer nå en kasuistikk om et alvorlig legionellosetilfelle sommeren $2020 \mathrm{i}$ Oslo (7.). Initialt fant ikke utbruddsteamet årsaken til smitten, til tross for at potensielle smittekilder som dusj, vannkran i hjemmet og på arbeidsplassen samt et bilvaskeanlegg, ble undersøkt. Mistanken til fontenen på Youngstorget kom som følge av informasjon fra pasientens samboer. Dette ledet til en utvidet miljøkartlegging, og miljøprøven fra fontenen viste høye verdier av Legionella pneumophila serogruppe 1. Sekvenstype 256 ble påvist i prøvene både fra fontenen og pasienten, og helgenomsekvensering viste at isolatene var identiske.

Oppfølgingen som beskrives i kasuistikken, viser hvor viktig det er å ha et bakterieisolat fra pasienten som kan sammenliknes med eventuelle funn etter en miljøundersøkelse, for med større sikkerhet å knytte infeksjonen til en smittekilde. Den viser også at det er viktig å ha en åpen holdning til hva som kan være smittekilden, etterforske bredt og ta prøver av relevante installasjoner.

\section{«Utendørsfontener $i$ Norge vil fortsatt ha lav risiko som smittekilde»}

Antigentest i urin identifiserer kun tilstedeværelse av Legionella pneumophila serogruppe 1. Dersom testen brukes alene, vil man ikke oppdage tilfeller forårsaket av andre arter/serogrupper av Legionella, såkalte ikke-Lp1-stammer ( $\underline{8})$. Det anbefales derfor at diagnostikk også inkluderer prøvetaking fra nedre luftveier, slik at eventuell sammenlikning med funn i miljøprøver kan gjennomføres med genteknologiske metoder. Ved utbrudd, kanskje spesielt vannbårne der det kan være multiple miljøkilder, har dette stor betydning for raskt å oppdage og fjerne smittekilden og stoppe utbruddet.

Så langt forfatterne kjenner til, er dette første gang en utendørsfontene blir påvist som smittekilde i Norge. Internasjonalt har flere innendørsfontener, men få utendørsfontener, blitt beskrevet som årsak til utbrudd (9.). Den nye kunnskapen er med på å endre risikobildet og fordrer oppdatering av råd og veiledning. Utendørsfontener i Norge vil fortsatt ha lav risiko som smittekilde, så lenge de driftes med kaldt vann fra drikkevannsnettet og dermed holder lav vanntemperatur. Hendelsen i 2020 viser likevel at det er viktig at fontener som resirkulerer vannet og dermed gir gunstige forhold for oppvekst av Legionella, også inkluderes i kommunenes risikoanalyse av aerosoldannende installasjoner.

\section{LITTERATUR}

1. World Health Organization. Legionellosis. https://www.who.int/news-room/factsheets/detail/legionellosis Lest 15.6.2021.

2. Wolff C, Lange H, Feruglio S et al. Evaluation of the national surveillance of Legionnaires' disease in Norway, 2008-2017. BMC Public Health 2019; 19: 1624. [PubMed][CrossRef]

3. European Centre for Disease Control and Prevention (ECDC). Legionnaires' disease - Annual Epidemiological Report for 2019. https://www.ecdc.europa.eu/en/publications-data/legionnairesdisease-annual-epidemiological-report-2019 Lest 15.6.2021.

4. European Centre for Disease Prevention and Control (ECDC). Legionnaires' disease - Annual Epidemiological report for 2018. https://www.ecdc.europa.eu/en/publications-data/legionnairesdisease-annual-epidemiological-report-2018 Lest 15.6.2021.

5. Montagna MT, De Giglio O, Napoli C et al. Control and prevention measures for legionellosis in hospitals: A cross-sectional survey in Italy. Environ Res 2018; 166: 55-60. [PubMed][CrossRef] 
6. Danila RN, Koranteng N, Como-Sabetti KJ et al. Hospital water management programs for legionella prevention, Minnesota, 2017. Infect Control Hosp Epidemiol 2018;39:336-8. [PubMed] [CrossRef]

7. Steen TW, Eggemoen ÅR, Andersen M et al. Legionellose etter smitte fra fontenen på Youngstorget. Tidsskr Nor Legeforen 2021; 141. doi: 10.4045/tidsskr.21.0092. [CrossRef]

8. Mercante JW, Winchell JM. Current and emerging Legionella diagnostics for laboratory and outbreak investigations. Clin Microbiol Rev 2015; 28: 95-133. [PubMed][CrossRef]

9. Correia AM, Gonçalves G, Reis J et al. An outbreak of legionnaires' disease in a municipality in northern Portugal. Euro Surveill 2001; 6:121-4. [CrossRef]

Publisert: 28. juni 2021. Tidsskr Nor Legeforen. DOI: 10.4045/tidsskr.21.0489

(C) Tidsskrift for Den norske legeforening 2023. Lastet ned fra tidsskriftet.no 26. april 2023. 